\title{
PELAKSANAAN LARANGAN PEMILIKAN TANAH PERTANIAN SECARA ABSENTEE DI KECAMATAN MAUK KABUPATEN TANGERANG (STUDI KASUS DI KANTOR PERTANAHAN KABUPATEN TANGERANG)
}

\author{
Nia Rosmiati \\ Amiludin \\ Niarosmiati12@gmail.com \\ tsamanytrans@gmail.com
}

\section{Fakultas Hukum Universitas Muhammadiyah Tangerang}

\begin{abstract}
ABSTRAK
Pemilikan tanah pertanian secara Absentee, secara tegas dilarang oleh Undang-Undang Pokok Agraria, larangan ini berkaitan dengan ketentuan-ketentuan pokok Landreform yang diatur dalam Pasal 7, 10 dan Pasal 17 UUPA. Kecamatan Mauk yang memiliki lahan seluas 18.644 ha setiap tahun semakin berkurang luasnya karena terjadinya peralihan lahan pertanian menjadi pemukiman. Selain hal tersebut kepemilikan lahan pertanian yang terjadi di Kecamatan Mauk kebanyakan dimiliki oleh orang yang berada di luar kecamatan Mauk itu sendiri. Penelitian ini penulis lakukan karena ingin mengetahui bagaimana pelaksannaan pelarangan tanah absentee/guntai di Kecamatan Mauk Kabupaten Tangerang dan juga penegakan hukum terhadap tanah absentee/guntai berdasarkan Undang Undang Pokok Agraria.Metode yang digunakan dalam penelitian ini adalah penelitian yuridis normatif empiris, maksud dari penelitian ini adalah mengkaji peraturan perundang-undangan dengan keadaan yang terjadi di masyarakat yang kemudian dianalisa dengan cara deskriptif kualitatif yang menggambarkan secara keseluruhan isi dan kualitas data tersebut.Hasil dari penelitian ini menjelaskan bahwa praktek pemilikan tanah absente di kecamatan mauk masih terjadi sampai saat ini dikarenakan pasal 7, 10 dan pasal 17 Undang-Undang Pokok Agraria tidak berjalan sebagaimana mestinya dan masih banyakanya faktor-faktor yang mempengaruhi dalam hal kepemilikan tanah secara absente di Kecamatan Mauk seperti faktor masyarakat, budaya, hukum, sarana prasarana, dan ekonomi. Penegakan hukum terhadap larangan pemilikan tanah absente sebagaimana yang tercantum dalam pasal Pasal 3 ayat 5 PP No. 224/1961 jo PP No 41 /1964 dengan cara retribusi tanah kepada rakyat yang membutuhkan seperti petani penggarap atau buruh tani tetap yang berkewarganegaraan Indonesia, bertempat tinggal di kecamatan tempat letak tanah yang bersangkutan dan kuat bekerja dalam pertanian.
\end{abstract}

Kata Kunci: Larangan Pemilikan, Tanah Pertanian, Absentee. 
JURNAL HUKUM REPLIK

Vol 7 No 2, September 2019

P-ISSN: 2337-9251, E-ISSN: 2597-9094

\begin{abstract}
Absentee ownership of agricultural land, is expressly prohibited by the Basic Agrarian Law, this prohibition relates to the main provisions of Land Reform which are regulated in Articles 7, 10 and Article 17 of the LoGA. Mauk Subdistrict, which has a land area of 18,644 ha, is decreasing in size every year due to the transition of agricultural land into settlements. In addition to this, agricultural land ownership in Mauk District is mostly owned by people outside the Mauk district itself. This research was conducted by the author because he wanted to find out how to ban absentee / guntai land in Mauk District, Tangerang Regency and also law enforcement on absentee / guntai land based on the Basic Agrarian Law. The method used in this study is empirical normative juridical research, the purpose of this research this is reviewing the laws and regulations with the conditions that occur in the community which are then analyzed in a qualitative descriptive way that illustrates the overall content and quality of the data. 7, 10 and article 17 of the Basic Agrarian Law are not functioning properly and there are still many factors that affect absent land ownership in Mauk District such as community, cultural, legal, infrastructure, and economic factors. Law enforcement against the prohibition of ownership of absentee land as stated in Article 3 paragraph 5 PP No. 224/1961 jo PP No. 41 / 1964 by way of land levies to people in need such as sharecroppers or permanent farm workers who are Indonesian citizens, residing in the sub-district where the land is concerned and strong in working in agriculture.

Keywords: Prohibition of Ownership, Agricultural Land, Absentee
\end{abstract}

\title{
I. Pendahuluan
}

Kabupaten Tangerang yang terdiri dari 29 Kecamatan dan salah satunya adalah yang akan dijadikan sebagai subjek penelitian ini adalah Kecamatan Mauk yang menurut penulis dan masyarakat yang banyak bercerita bahwa banyak tanah absente baik yang dimiliki oleh warga masyarakat biasa maupun para pegawai negeri sipil. Dari seluruh tanah absente tersebut ada yang masih tetap dimiliki pemiliknya dan ada juga yang sudah diredistribusi termasuk banyaknya juga tanah yang diterlantarkan oleh para pemiliknya dan penulis berpendapat bahwa akibat hal ini terjadi suatu kesenjangan antara tujuan dari yang ingin dicapai dengan kenyataan dilapangan.

Luas area persawahan di Kecamatan Mauk seluas 18.644 ha yang semakin hari luas tersebut berkurang karena banyaknya peralihan hak atas tanah dan termasuk terjadinya konversi lahan pertanian menjadi perumahan yang dilakukan oleh masyarakat setempat. Kenyataan yang terjadi dilapangan adalah terkait larangan terhadap pemilikan tanah secara absentee tidak berlaku, pemilikan dan/atau penguasaan tanah pertananian secara absentee juga banyak dijumpai sampai sekarang di Kecamatan Mauk. Dan Kecamatan Mauk merupakan salah satu Kecamatan yang bisa dibilang sebagai penghasil padi terbaik di wilayah Kabupaten Tangerang.

Pemilikan tanah pertanian secara absentee di Kecamatan Mauk menjadi suatu permasalahan sosial karena Mauk memiliki tanah yang subur dan 
JURNAL HUKUM REPLIK

Vol 7 No 2, September 2019

P-ISSN: 2337-9251, E-ISSN: 2597-9094

masyarakat yang mayoritas sebagai petani yang harus mengikuti arus perekonomian yang menuntut adanya pelaksanaan larangan pemilikan tanah pertanian secara absentee. Penyusutan hasil pertanian di Kecamtan Mauk dapat dilihat dari data yang didapat melalui pengkajian terhadap laporan tahunan Dinas Pertanian Kabupaten Mauk dan data terkait pertanian di Kecamatan Mauk. Dasar hukum dari pada larangan pemilikan tanah secara absentee ini adalah Pasal 10 Ayat (1) UUPA, yaitu setiap orang yang mempunyai sesuatu hak atas tanah pertanian pada dasarnya diwajibkan mengerjakan atau mengusahakannya sendiri secara aktif, dengan mencegah cara-cara pemerasan.

Pemilikan tanah pertanian secara Absentee, secara tegas dilarang oleh UUPA. Larangan ini berkaitan dengan ketentuan-ketentuan pokok Landreform yang diatur dalam Pasal 7, 10 dan Pasal 17 UUPA. Maksud dari larangan pemilikan tanah secara absentee ini adalah agar petani bisa aktif dan efektif dalam mengerjakan tanah pertanian miliknya, sehingga produktifitasnya bisa tinggi dan melenyapkan pengumpulan tanah di tangan segelintir tanah-tuan tanah.

Sebagaimana telah dijelaskan di atas, bahwa meskipun pemilikan tanah pertanian secara absentee dilarang, tetapi sampai saat ini masih, berdasarkan hasil penelitian penulis di lapangan, masih dijumpai adanya pemilikan tanah pertanian secara absentee di Kecamatan Mauk. Hal ini dapat ditunjukkan pada bukti tempat tinggal/domisili pemilik tersebut adalah di luar Kecamatan tetapi pada kenyataannya memiliki tanah pertanian di Kecamatan tersebut.

Pembahasan tanah absentee sebelumnya pernah dilakukan oleh Juraida dalam sebuah skripsi di Universitas Islam Negeri Sunan Kali Jaga Yogyakarta dalam penelitian ini pembahasannya lebih kepada kajian normatif terkait undangundang pokok agraria dan peraturan pelaksanannya yang dianggap masih belum optimal dikarenakan peraturan tersebut belum bisa mencegah terkait praktek penguasan tanah secara absentee.

Berbeda yang akan dibahas oleh penulis dalam penelitian ini adalah larangan pelaksanaan pemilikan tanah secara absentee oleh Kantor BPN Kabupaten Tangerang, dan penegakan hukum terhadap tanah absentee berdasarkan undang-undang pokok agraria, sehingga penulis beranggapan butuh penelitian lebih mendalam dan menganalisa terkait masalah tersebut, agar praktek monopoli pertanahan tidak hanya dikuasai oleh mereka yang mempunyai modal banyak.

Berdasarkan hal tersebu penulis ingin membahas dan menganalisa lebih jauh terkait larangan tanah absente di wilayah Kecamatan Mauk dengan judul Pelaksanaan Larangan Pemilikan Tanah Pertanian Secara Absentee Di 
JURNAL HUKUM REPLIK

Vol 7 No 2, September 2019

P-ISSN: 2337-9251, E-ISSN: 2597-9094

\section{Kecamatan Mauk Kabupaten Tangerang (Studi kasus di Kantor Pertanahan Kabupaten Tangerang).}

Berdasarkan latar belakang yang telah diuraikan maka Bagaimana pelaksanaan pelarangan pemilikan tanah secara absentee di Kecamatan Mauk Kabupaten Tangerang dan Bagaimana penegakan hukum terhadap pemilikan tanah secara absentee di Kecamatan Mauk Kabupaten Tangerang.

Suatu penelitian yang dilakukan tentu harus mempunyai tujuan yang akan diperoleh dari sebuah hasil penelitian Untuk mengetahui dan menganalisa pelaksanaan pelaranagn tanah secara abseente di Kecamatan Mauk Kabupaten Tangerang dan Untuk mengetahui dan menganalisa penegakan hukum terhadap pemilikan tanah secara absentee berdasarkan UUPA.

\section{Metode Penelitian}

Dengan sumber data yang terdiri dari data primer yang mana data diperoleh secara langsung melalui wawancara, observasi maupun laporan. Data yang diperoleh dari lapangan yang berasal dari Kecamatan Mauk dan Kantor BPN Kab Tangerang. Penelitian lapangan dalam hal ini adalah data atau dokumendokumen yang berkaitan dengan obyek penelitian. Sedangkan data sekunder adalah data yang diperoleh peneliti dari sumber yang sudah ada. Data yang diperoleh dan bersumber dari peraturan perundang-undangan yang berlaku tentang tanah absentee yang tercantum dalam undang-undang pokok agraria dan buku-buku yang ada kaitanya dengan masalah yang akan diteliti. Data sekunder dibagi lagi menjadi beberapa macam yaitu Bahan hokum primer, Bahan hukum sekunder dan bahan hukum tersier.

\section{Hasil Penelitian dan Analisa}

1. Faktor Penyebab Tanah Absente Dan Peran Bpn Kabupaten Tangerang Dalam Mengatasi Kepemilikan Tanah Absente Di Kecamatan Mauk

Pemerintah Kabupaten Tangerang, Banten, menetapkan Kecamatan Mauk dan Sepatan sebagai lumbung padi abadi untuk mendukung swasembada pangan memenuhi kebutuhan sekitar 3,2 juta penduduk daerah itu. Penetapan itu telah sesuai dengan Rencana Tata Ruang Wilayah (RTRW) dan Rencana Pembangunan Jangka Menengah Daerah (RPJMD), sebagaimana yang telah disampaikan oleh Bupati Tangerang Ahmed Zaki dalam wawancaranya dengan salah satu media online bahwa penetapan 
JURNAL HUKUM REPLIK

Vol 7 No 2, September 2019

P-ISSN: 2337-9251, E-ISSN: 2597-9094

Kecamatan Mauk dan Sepatan sebagai sebagai lumbung beras yang areal persawahan tidak boleh dijual. ${ }^{1}$

Pernyataan yang disampaikan oleh Bupati Tangerang ini secara tidak langsung memberikan sebuah ketetapan bahwa untuk wilayah mauk yang mana sawah tidak boleh diperjualbelikan untuk kegiatan lain, tetap ada sedikit permasalahan yang dianggap oleh penulis bahwa kesuksesan kecamatan mauk yang ditetapkan sebagai lumbung padi ternyata tidak berdampak secara ekonomi bagi para petani dikarenakan posisi petani yang ada sekarang ini hanyalah sebagai buruh tani.

Permasalahan yang lain adalah larangan kepemilikan tanah secara absentee ini adalah Pasal 10 Ayat (1) UUPA, yaitu setiap orang yang mempunyai sesuatu hak atas tanah pertanian pada dasarnya diwajibkan mengerjakan atau mengusahakannya sendiri secara aktif, dengan mencegah cara-cara pemerasan, Pemilikan tanah pertanian secara Absentee, secara tegas dilarang oleh UUPA. Larangan ini berkaitan dengan ketentuanketentuan pokok Landreform yang diatur dalam Pasal 7, 10 dan Pasal 17 UUPA. Maksud dari larangan pemilikan tanah secara absentee ini adalah agar petani bisa aktif dan efektif dalam mengerjakan tanah pertanian miliknya, sehingga produktifitasnya bisa tinggi dan melenyapkan pegumpulan tanah di tangan segelintir tanah-tuan tanah.

salah satu sebab timbulnya pemilikan tanah pertanian secara absentee adalah petani pemilik tanah kadang-kadang dalam keadaan mendesak memerlukan uang yang diharapkan dari hasil penjualan tanahnya dapat membantu kebutuhannya sehingga pemilik uang yang berada di kota membeli tanah tersebut dan berakhir pada penguasaan tanah sehingga tanah yang tanah yang telah dikuasai tidak dapat dimanfaatkan oleh petani dan berakibat kepada penelantaran tanah.

1 Esthi Maharani, Mauk dan Sepatan Ditetapkan Sebagai Lumbung Padi Abadi, https://www.republika.co.id/berita/nasional/jabodetabek-nasional/15/04/19/nn1s51-mauk-dansepatan-ditetapkan-sebagai-lumbung-padi-abadi, diakses pada tanggal 16 Juli 2018 Pukul 21:35 WIB 
JURNAL HUKUM REPLIK

Vol 7 No 2, September 2019

P-ISSN: 2337-9251, E-ISSN: 2597-9094

\section{Peran Badan Pertanahan Nasional Kabupaten Tangerang dalam Mengatasi Kepemilikan Tanah Absente di Kecamtan Mauk}

Tanggung jawab yang di bebankan kepada Badan Pertanahan Nasional untuk dapat memecahkan berbagai macam persoalan yang muncul di bidang pertanahan tentu sangatlah berat. Demikian juga halnya dengan Badan Pertanahan Nasional yang ada di daerah Kabupaten Tangerang terkait permasalahan kepemilikan tanah absentee atau tanah yang dimiliki orang lain diluar kecamatan sehingga kewenangan pemerintah untuk melakukan perbuatan hukum baik itu berhubungan dengan hukum publik maupun dengan hukum privat, harus bersumber dari peraturan perundang-undangan. Kewenangan itu sendiri memiliki arti sebagai hak dan kekuasaan untuk bertindak, atau juga memerintah. Menurut Philipus M. Hadjon sendiri membagi cara memperoleh wewenang atas dua cara, yaitu: "atribusi; dan delegasi dan juga mandat".

Konsep Negara hukum ini harus memberikan suatu alat sebagai jaminan bagi organ pemerintah dalam menjalankan tugasnya. Sehingga tindakan hukum yang dilakukan pemerintah dilakukan berdasarkan wewenang yang sah dan tanggung jawab dari wewenang yang dilakukannya. Larangan pemilikan tanah pertanian secara absentee walaupun sudah diatur dalam Peraturan Pemerintah Nomor 224 Tahun 1961 yang dirubah dengan Peraturan Pemerintah Nomor 41 Tahun 1964 tentang Pelaksanaan Pembagian Tanah dan Pemberian Ganti Rugi dan ditegaskan kembali dalam Peraturan Menteri Agraria Dan Tata Ruang/ Kepala Badan Pertanahan Nasional Nomor 18 Tahun 2016 Tentang Pengendalian Penguasaan Tanah Pertanian, berdasarkan penelitian dilapangan di Kabupaten Tangerang masih terdapat tanah yang pemilikannya dimiliki secara absentee, sejauh ini Kantor Badan Pertanahanan Kabupaten Tangerang belum banyak melakukan tindakan untuk menanggulangi masalah ini, hal ini dibuktikan dengan masih banyaknya pemilikan tanah secara absentee di Kecamatan Mauk.

Peran Badan Pertanahan Nasional yang memiliki tugas dan kewajiban dibidang pertanahan dipertegas dalam Peraturan Presiden Nomor 20 Tahun 2015 tentang Badan Pertanahan Nasional. Dalam salah satu pertimbangan terbitnya Peraturan Presiden ini adalah bahwa tanah merupakan perekat Negara Kesatuan Republik Indonesia sehingga perlu diatur dan dikelola secara nasional untuk menjaga keberlanjutan sistem kehidupan berbangsa dan bernegara. 
JURNAL HUKUM REPLIK

Vol 7 No 2, September 2019

P-ISSN: 2337-9251, E-ISSN: 2597-9094

Kemudian dijabarkan dalam Peraturan Kepala Badan Pertanahan Nasional Republik Indonesia Nomor 3 Tahun 2011 tentang Pengelolaan Pengkajian Dan Penanganan Kasus Pertanahan. Kantor Pertanahan Kabupaten Tangerang bertanggung jawab dalam mengatasi kepemilkan tanah secara Absentee yang merupakan tindak lanjut dari wewenang yang dimiliki oleh Badan Pertanahan Nasional yang berdasarkan Pasal 2 ayat (1b) Peraturan Kepala Badan Pertanahan Nasional Nomor 3 Tahun 2011 tentang Pengelolaan Pengkajian Dan Penanganan Kasus Pertanahan yang menyatakan Badan Pertanahan harus "Meyelesaikan kasus pertanahan yang disampaikan kepada kepala Badan Pertanahan Nasional agar tanah dapat dikuasai, dimiliki, dipergunakan dan dimanfaatkan oleh pemiliknya serta dalam rangka kepastian dan perlindungan hukum. Badan pertanahan Nasional juga bertanggung jawab atas segala persoalan menganai tanah dan tentu juga mengenai pemilikan tanah Pertanian Absentee yang telah dimiliki oleh orang diluar Wilayah Kecamatan letak tanah itu berada.

Peran yang akan dilakukan Badan Pertanahan Nasional Kabupaten Tangerang sebagaimana yang penulis dapatkan dalam hasil wawancara dengan Bapak Asep Erwin SH bahwa langkah pertama yang akan dilakukan oleh pihak BPN Kabupaten Tangerang adalah dengan cara menolak permohonan untuk hak milik atas tanah tersebut apabila domisili pemilik tersebut berbeda dengan lokasi tanah yang akan di ajukan haknya kepada BPN. Ketentuan ini sesuai dalam Pasal 6 ayat (1) Peraturan Meteri Negara Agraria/ Kepala Badan Pertanahan Nasional Nomor 9 Tahun 1999 Tentang Tata Cara Pemberian Dan Pembatalan Hak Atas Tanah Negara Dan Hak Pengelolaan,yangmenyebutkan "Keputusan pembatalan hak atas tanah karena cacat hukum administratif dalam penerbitannya, dapat dilakukan karena permohonan yang berkepentingan atau oleh Pejabat yang berwenang tanpa permohonan. "Cacat hukum administratif yang disebutkan dalam Pasal 106 ayat (1) antara lain:
a. Kesalahan prosedur;
b. Kesalahan penerapan peraturan perundang-undangan;
c. Kesalahan subjek hak;
d. Kesalahan objek hak;
e. Kesalahan jenis hak;
f. Kesalahan perhitungan luas;
g. Terdapat tumpang tindis hak atas tanah;
h. Data yuridis atau data fisik tidak benar; atau 
JURNAL HUKUM REPLIK

Vol 7 No 2, September 2019

P-ISSN: 2337-9251, E-ISSN: 2597-9094

i. Kesalahan lainnya yang bersifat hukun administratif.

Upaya selanjutnya yang dilakukan oleh BPN Kabupaten Tangerang dalam hal larangan pemilikan tanah absentee Peraturan Menteri Agraria Dan Tata Ruang/ Kepala Badan Pertanahan Nasional Nomor 18 Tahun 2016 pasal 7 ayat (1) menjelaskan bahwa Pemilik tanah pertanian yang bertempat tinggal di luar kecamatan tempat letak tanah dalam waktu 6 (enam) bulan sejak tanggal perolehan hak harus mengalihkan hak atas tanahnya kepada pihak lain yangberdomisili di kecamatan tempat letak tanah tersebut atau pindah ke kecamatan letak tanah tersebut.

Larangan kepemilikan tanah absente dikecamatan mauk atau BPN Kabupaten Tangerang sendiri tidak bisa maksimal walaupun secara regulasi pemerintah sudah membuat sebuah peraturan terkait larangan tersebut. Adapun hambatan yang membuat larangan kepemilikan tanah absente tidak berjalan sebagaimana mestinya karena sering sekali terjadi kompromi baik dari tingkat kecamatan atau keluarhan dalam membantu pembeli untuk dibuatkan Kartu Tanda Penduduk ganda dan pemberian sanksi yang tidak maksimal yang akhirnya para pemilik modal tidak merasa takut untuk melakukan atau memiliki tanah diluar kecamatan tempat tinggalnya.

\section{Pelaksanaan Pelarangan Tanah Absente Dan Penegakan Hukum Bagi Pemilik Tanah Absente Berdasarkan Undang-Undang Pokok Agraria Nomor 6 Tahun 1960}

Indonesia sebagai negara agraris, setelah kemerdekaan (1945) menghadapi masalah mendasar di bidang hukum pertanahan, yaitu terdapatnya masalah kepemilikan tanah yang tidak proporsional dan kebutuhan tanah pertanian yang meningkat terus di dorong oleh pertambahan penduduk. Dalam rangka mengatasi masalah di atas sebagai negara merdeka yang berdaulat penuh berusaha untuk mengatur kehidupan bernegara dengan mewujudkan hukum Agraria Nasional.

Tanah merupakan sumber daya yang penting bagi masyarakat, baik sebagai media tumbuh tanaman, maupun sebagai ruang atau wadah tempat melakukan berbagai kegiatan. Indonesia merupakan negara yang sebagian besar penduduknya bermata pencaharian di bidang pertanian, baik sebagai pemilik tanah pertanian, petani penggarap maupun buruh tani. Sebagai pelaksanaan dari Undang-undang Nomor 5 Tahun 1960 tentang Peraturan 
JURNAL HUKUM REPLIK

Vol 7 No 2, September 2019

P-ISSN: 2337-9251, E-ISSN: 2597-9094

Dasar Pokok-pokok Agraria (UUPA) pemerintah mengeluarkan UU No. 56 Prp Tahun 1960 tentang Penetapan Luas Tanah Pertanian diatur lebih lanjut dengan Peraturan Menteri Agraria Dan Tata Ruang/Kepala Badan Pertanahan Nasional Nomor 18 Tahun 2016 Tentang Pengendalian Penguasaan Tanah Pertanian, masih banyak terdapat orang yang memiliki tanah pertanian secara absentee/guntai, sehingga dalam prakteknya adanya peraturan mengenai larangan tanah absentee/guntai belum bisa diterapkan secara efektif. ${ }^{2}$

Dalam pasal 10 Undang-Undang No. 5 Tahun 1960 Tentang Peraturan Dasar Pokok-Pokok Agraria yang dikenal dengan Undang-Undang Pokok Agraria (UUPA) disebutkan bahwa, "Setiap orang dan badan hukum yang mempunyai sesuatu hak atas tanah pertanian pada asasnya diwajibkan mengerjakan atau mengusahakan sendiri secara aktif, dengan mencegah cara-cara pemerasan".

Asas ini berarti pemilik tanah pertanian mengerjakan atau mengusahakan sendiri tanahnya dan masih diperbolehkan menggunakan tenaga buruh tetapi harus dicegah praktek cara-cara pemerasan. Pemberian upah yang terlampau rendah kepada buruh-tani yang membantu mengerjakan dan mengusahakan tanah yang bersangkutan merupakan "exploitation de l'homme par l'homme" merupakan cara pemerasan, yang bertentangan dengan cita-cita keadilan. ${ }^{3}$

Langkah pertama ke arah pelaksanaan asas tersebut, bahwa pemilik tanah pertanian wajib mengerjakan atau mengusahakannya sendiri secara aktif maka diadakan ketentuan untuk menghapuskan penguasaan tanah pertanian secara absentee atau dalam bahasa sunda : "Guntai," dengan dikeluarkannya peraturan pelaksana UUPA berupa Peratuan Pemerintah No. 224 Tahun 1961 tentang Pelaksanaan Pembagian Tanah dan Pemberian Ganti Kerugian jo Peratuan Pemerintah No.41 Tahun 1964 tentang Perubahan dan Penambahan Peratuan Pemerintah No. 224 Tahun 1961. Secara substansi larangan pemilikan tanah pertanian secara absentee diatur dalam pasal 3 PP No. 224 / 1961 jo Pasal I PP No. 41 / 1964 tambahan Pasal 3 a sampai dengan 3e) Sedang dasar hukumnya adalah Pasal 10 ayat 2

${ }^{2}$ Anastasia Apsari Astutiningsih, Isharyanto, peran kantor pertanahan terhadap pelaksanaan larangan kepemilikan tanah secara absenteel guntai di kabupaten sukoharjo, Jurnal Repertorium, Vol. Vol. No. 1 Tahun 2018 https://jurnal.uns.ac.id/repertorium/article/view/18222 diakses pada tangga; 14 juli 2018 pukul 11:30 WIB

${ }^{3}$ Boedi Harsono, Op.Cit. hlm. 238-239 
JURNAL HUKUM REPLIK

Vol 7 No 2, September 2019

P-ISSN: 2337-9251, E-ISSN: 2597-9094

UUPA. Pada pokoknya dilarang pemilikan tanah pertanian oleh pemilik yang bertempat tinggal di luar kecamatan tempat letak tanahnya.

Yang dimaksud tanah pertanian dijelaskan dalam Intruksi Bersama Menteri Dalam Negeri dan Otonomi Daerah dengan Menteri Agraria tanggal 5 Januari 1961 No. sekra 9/1/12 sebagai berikut: "Tanah pertanian ialah juga semua tanah perkebunan, tambak untuk perikanan, tanah tempat penggembalaan ternak, tanah belukar bekas ladang dan hutan yang menjadi tempat mata pencaharian bagi yang berhak”.

Pada umumnya tanah pertanian adalah semua semua tanah yang menjadi hak orang selain tanah untuk perumahan dan perusahaan. Bila atas sebidang tanah luas berdiri rumah tempat tinggal seseorang, maka pendapat setempat itulah yang menentukan, berapa luas yang dianggap halaman rumah dan berapa yang merupakan tanah pertanian ". 4

Sebelum berlakunya Peratuan Pemerintah No. 224 Tahun 1961, mengenai pemilikan tanah pertanian secara absentee tidak dilarang. Baru sudah berlakunya PP No. 224 / 1961 pada tanggal 24 September 1961 adanya larangan pemilikan tanah pertanian secara absentee. Untuk itu kepada pemilik tanah pertanian absentee di dalam jangka waktu 6 bulan sejak tanggal 24 September 1961 wajib mengalihkan hak atas tanahnya kepada orang lain di kecamatan tempat letak tanah yang bersangkutan atau pindah ke kecamatan tersebut (pasal 3 ayat 1 PP No. 224 Tahun 1961) bahwa kenyataan jangka waktu 6 bulan untuk mengalihkan tanah - tanah pertanian absentee itu tidak cukup. Maka oleh Menteri Agraria diambil kebijaksanaan untuk memperpanjangnya hingga tanggal 31 Desember 1962 (Keputusan Menteri Agraria No. SK.VI/6/Ka/1962).

Tentu saja, dilarang semua bentuk pemindahan hak milik atas tanah pertanian yang menimbulkan pemilikan secara absentee (pasal $3 \mathrm{~d}$ PP. No. 224/1961 jo PP No. 41 / 1964 ). Pemilikan tanah pertanian absentee ada perkecualiannya yaitu terhadap Pemilik yang bertempat tinggal di kecamatan yang berbatasan dengan kecamatan tempat letak tanah yang bersangkutan berdasarkan pertimbangan panitia Landreform Daerah Tingkat II dinilai efisien untuk mengerjakan tanah tersebut. Pegawai negeri dan Pensiunan pegawai negeri juga terhadap janda pegawai negeri dan janda pensiunan pegawai negeri seluas $2 / 5$ dari luas maksimum untuk Daerah Tingkat II yang bersangkutan. Mereka yang sedang menjalankan tugas

4 Kumpulan Peraturan Perundang-undangan Landreform di Indonesia Beserta Petunjuk Pelaksanaanya , 1981 hlm. 148 
JURNAL HUKUM REPLIK

Vol 7 No 2, September 2019

P-ISSN: 2337-9251, E-ISSN: 2597-9094

Negara, menunaikan kewajiban agama atau mempunyai alasan khusus lainnya yang dapat diterima pada waktu itu oleh Menteri Agraria (sekarang Kepala Kantor Badan Pertanahan Nasional).

Tujuan larangan pemilikan tanah pertanian secara absentee ini sesuai dengan tujuan landreform yang sudah dilaksanakan di berbagai negara untuk menghapuskan sistem absentee/absenty landlord yang merugikan buruh tani. Tujuan landreform secara langsung memeratakan Hak Atas Tanah kepada sebanyak mungkin petani dengan cara membagikan kembali tanah luas milik tuan tanah kepada orang yang tidak menggarap tanah itu dan tujuan landreform secara tidak langsung adalah untuk meniadakan keresahan sosial yang ada di daerah pertanian yang disebabkan oleh penguasa tanah untuk segolongan kecil manusia yang tidak menggarap sendiri tanahnya.

\section{Penegakan Hukum Terhadap Pemilikan Tanah Secara Absentee dan Peredistribusian Tanah Absente Bagi Masyarakat yang Tidak Mampu}

Demi tercapainya cita-cita negara Indonesia yang tertuang dalam alinea ke-4 pembukaan UUD 1945, yakni “. . . . untuk memajukan kesejahteraan umum", tanah merupakan hal sangat penting khususnya bagi masyarakat yang bermata pencaharian sebagai petani. Kegelisihan yang terjadi di kalangan masyarakat saat ini, banyaknya tanah-tanah pertanian di daerah maupun di kota sekalipun yang terlantar dan tidak di kelola oleh pemiliknya dengan baik. Sehingga dalam hal ini, menimbulkan sesuatu yang tidak produktif bagi masyarakat di sekitar tanah yang ditelantarkan tersebut.

Jika kita berbicara tentang Keadilan, berangkat dari Sila ke-5 Pancasila yakni, "Keadilan Sosial Bagi Seluruh Rakyat Indonesia", keadilan merupakan salah satu tujuan negara Indonesia. Sila keadilan sosial bagi seluruh rakyat Indonesia menunjukkan bahwa masyarakat Indonesia menyadari hak dan kewajiban yang sama untuk menciptakan keadilan sosial. Penegakkan keadilan merupakan salah satu upaya dari Pemerintah untuk menerapkan hukum yang sudah berlaku di Indonesia yang akan membuat kehidupan masyarakat Indonesia menjadi aman dan tenteram sekaligus untuk memajukan kesejahteraan umum sesuai dengan cita-cita bangsa Indonesia.

Berangkat dari pasal 33 ayat (3) UUD 1945, "Bumi dan air dan kekayaan alam yang terkandung di dalamnya dikuasai oleh negara dan dipergunakan untuk sebesar-besar kemakmuran rakyat"4. Bunyi pasal tersebut menyinggung tentang bagaimana kemakmuran rakyat itu bisa 
JURNAL HUKUM REPLIK

Vol 7 No 2, September 2019

P-ISSN: 2337-9251, E-ISSN: 2597-9094

dicapai. Menuju pasal 10 ayat (1) Undang-undang Nomor 5 Tahun 1960 tentang Pokok-pokok Agraria, bahwa pemilik tanah pertanian diwajibkan untuk mengerjakan dan mengusahakan sendiri tanah pertaniannya. Pelaksanaan Undang-Undang (UU) Nomor 5 Tahun 1960 tersebut yakni Peraturan Pemerintah (PP) Nomor 224 Tahun 1961 tentang Pelaksanaan Pembagian Tanah dan Pemberian Ganti Kerugian dalam Pasal 3 ayat (1), yang berbunyi "Pemilik tanah yang bertempat tinggal diluar kecamatan tempat letak tanahnya, dalam jangka waktu 6 bulan wajib mengalihkan hak atas tanahnya kepada orang lain di kecamatan tempat letak tanah itu atau pindah ke kecamatan letak tanah tersebut.

Dipertegas kembali dengan terbitnya Peraturan Menteri Agraria dan Tata Ruang/Kepada Badan Pertanahan Nasional Republik Indonesia (Permentan) Nomor 18 Tahun 2016 tentang Pengendalian Penguasaan Tanah Pertanian pasal 7 ayat (1), yang berbunyi: "Pemilik tanah yang pertanian bertempat tinggal diluar kecamatan tempat letak tanah dalam jangka waktu 6 (enam) bulan sejak tanggal perolehan hak." Tanah pertanian yang terlantar dalam istilah hukum agraria adalah tanah absentee. Tanah absentee adalah tanah yang letaknya berjauhan dengan pemiliknya Tanah pertanian berhubungan erat dengan program landreform. Pengaruh landreform dan pertanian secara timbal balik sudah jelas karena salah satu tujuan dari program tersebut adalah peningkatan produktifitas. Tanah absentee tersebut menghambat salah satu proses peningkatan produktifitas yang merupakan tujuan dari program landreform.

Penegakkan hukum adalah proses dilakukannya upaya untuk tegaknya atau berfungsinya norma-norma hukum secara nyata sebagai pedoman perilaku dalam lalu lintas atau hubungan-hubungan hukum dalam kehidupan bermasyarakat dan bernegara. ${ }^{5}$ Untuk mewujudkan apa yang dinamakan Penegakkan Hukum, maka dalam hal ini faktor-faktor yang sudah dijelaskan sebelumnya haruslah sudah paham dan mengerti tentang apa itu tanah absentee. Dilihat dari segi substansinya, hukum tersebut benarbenar jelas melarang adanya kepemilikan tanah absentee. Akan tetapi, sanksi pidana yang terdapat dalam PP No. 224 tahun 1961 pasal 19, masih belum terlihat tegas dan hanya berupa pelanggaran. Menurut penulis perlu kiranya ada sanksi yang lebih tegas sehingga warga atau masyarakat sampai dengan

${ }^{5}$ Jimly Asshiddiqie, Penegakan Hukum, Makalah yang dipublikasikan dalam http://jimly.com/ pemikiran/makalah?page=12, 2002, diakses pada tanggal 25 Juli 2018 Pukul 21:45 
JURNAL HUKUM REPLIK

Vol 7 No 2, September 2019

P-ISSN: 2337-9251, E-ISSN: 2597-9094

alat hukumnya benar-benar tidak akan melakukan pelanggaran tersebut. Sanksi pidana yang diterapkan dalam peraturan tersebut meliputi, pertama, Pemilik Tanah yang menolak atau dengan sengaja menghalang-halangi pengambilan tanah oleh Pemerintah. Kedua, kepada barangsiapa dengan sengaja menghalangi terlaksananya Peraturan Pemerintah tersebut. Namun, peneliti masih belum menemukan adanya sanksi pidana bagi alat hukum (Notaris, PPAT dan Pihak BPN) yang dalam hal ini sangat berperan penting untuk menegakkan peraturan tersebut. Tindakan langkah preventif yang mungkin bisa dipertimbangkan, yakni perlu adanya hukum atau sanksi pidana mengikat kepada alat hukum. Kemudian jika alat hukumnya sudah patuh terhadap hukum, masyarakat yang menjadi korban ataupun pelaku dari pemilik tanah absentee bisa taat dan patuh terhadap hukum.

Berdasarkan permasalahan di atas, solusi dan langkah preventif yang di sarankan oleh peneliti perlu adanya penyuluhan hukum sekaligus pemahaman tentang landreform khususnya tanah absentee sendiri. Guna mengurangi ketidakpahaman sampai ketidaktahuan hukum atau permasalahan tanah absentee. Walaupun jika kita melihat asas hukum yakni asas fiksi hukum, tidak ada peraturan yang mengikat bagi alat hukum sendiri. Hal tersebut, menjadi suatu problematika tersendiri dan apabila substansi dari hukum tersebut sudah ditambahkan barulah untuk pemahaman bagi alat hukum yang sudah mengetahui dan belum mengetahui dapat berjalan dengan adanya penyuluhan hukum tersebut.

Berbicara masyarakat, banyak sekali yang belum mengerti tentang tanah absentee. Bahkan masyarakat disana belum tahu sama sekali terkait tanah absentee, walaupun dalam hal ini mereka mengetahui tentang tanah yang terlantar karena tidak dikerjakan oleh pemiliknya. Kurangnya sosialisasi terkait masalah tanah absentee dan penyuluhan tentang hukumnya sendiri, membuat masyarakat masih buta terhadap hukum. Ketidaktahuan dan ketidakpahaman masyarakat membuat hukum tersebut tidak akan bisa ditegakkan. Walaupun dalam hal ini jika kita menerapkan asas fiksi hukum, masyarakat malah menganggap hal itu sudah biasa dan bukan menjadi permasalahan.

Tanah-tanah pertanian absentee dalam rangka pelaksanaan program landreform yang terkena PP No. 224/1961 jo PP No. 41/ 1964, oleh pemerintah diredistribusikan kepada rakyat yang membutuhkan, dan kepada bekas pemilik tanah pertanian secara absentee diberikan ganti kerugian. Serta untuk mencegah terjadinya penyelundupan pemilikan tanah pertanian 
JURNAL HUKUM REPLIK

Vol 7 No 2, September 2019

P-ISSN: 2337-9251, E-ISSN: 2597-9094

secara absentee, pemerintah berupaya untuk melakukan tindakan preventif dan refresif.

Upaya hukum atau penegakan hukum terhadap larangan pemilikan tanah absente pemerintah membuat sebuah kebijakan tanah yang harus direbistribusikan kepada rakyat yang membutuhkan dengan cara tanah-tanah yang diredistribusikan dalam rangka landreform tidak hanya tanah absentee sebagaimana dimaksud dalam Pasal 3 ayat 5 PP No. 224/1961 jo PP No 41 /1964 melainkan pula tanah kelebihan batas maksimun berdasarkan UU No. 56/Prp/ 1960 serta tanah-tanah yang jatuh kepada negara karena subyek haknya melanggar ketentuan landreform, tanah swapraja dan tanah negara eks swapraja yang beralih kepada negara sebagai mana dimaksud diktum keempat huruf A UU No. 5 tahun 1960 dan tanah-tanah lain yang dikuasai langsung oleh negara yang akan ditegaskan lebih lanjut oleh Menteri Agraria.

Penguasaan tanah-tanah kelebihan maksimum dan tanah bekas absentee dimulai pada tanggal 24 September 1961 secara berangsur-angsur, setelah ditetapkan bagian mana yang akan dikuasai oleh pemerintah maka tanah-tanah yang bersangkutan di ijinkan untuk dikerjakan oleh para petani penggarapnya untuk paling lama 2 tahun dengan kewajiban membayar sewa kepada pemerintah sebesar $1 / 3$ dari hasil panen atau uang yang senilai dengan itu (pasal 14 ayat 1 PP No. 224 / 1961).

Syarat-syarat yang harus dipenuhi oleh mereka yang akan menerima redistribusi tanah, yaitu petani penggarap atau buruh tani tetap yang berkewarganegaraan Indonesia, bertempat tinggal di kecamatan tempat letak tanah yang bersangkutan dan kuat bekerja dalam pertanian. Tempat tinggal ini masih dapat dispensasi sesuai dengan ketentuan tentang absentee yaitu tidak ada keberatan jika petani penggarap bertempat tinggal yang berbatasan dengan letak tanahnya asal jarak antara tempat tinggal penggarap dan tanah yang bersangkutan masih memungkinkan mengerjakan tanah itu secara efisien (pasal 3 ayat (2) PP No. 224 / 1961).

Oleh karena luas tanah yang akan diredistribusikan sangat sedikit jika dibandingkan dengan jumlah petani yang membutuhkan maka diadakan prioritas dalam pembagiannya. Para penggarap tanah yang bersangkutan mendapat prioritas pertama karena mereka mempunyai hubungan yang paling erat dengan tanah yang digarapnya sehingga atas dasar prinsip "tanah untuk tani yang menggarap" hubungan tersebut tidak boleh dilepaskan, bahkan harus dijamin kelangsungannya ( penjelasan pasal 8 PP No. 224 / 
JURNAL HUKUM REPLIK

Vol 7 No 2, September 2019

P-ISSN: 2337-9251, E-ISSN: 2597-9094

$1961)$.

Pasal 8 PP No. 224/1961 apabila setelah dibagikan kepada golongan petani penggarap yang mengerjakan tanah yang bersangkutan sebagai prioritas pertama masih ada sisa, maka sisanya dibagikan berdasarkan prioritas berikutnya yang terdiri dari:

a. Buruh tani tetap pada bekas pemilik, yang mengerjakan tanah yang bersangkutan;

b. Pekerja tetap pada bekas pemilik tanah yang bersangkutan ;

c. Penggarap yang belum sampai 3 tahun mengerjakan tanah yang bersangkutan

d. Penggarap yang mengerjakan tanah hak pemilik;

e. Penggarap tanah-tanah yang oleh pemerintah diberikan untuk peruntukan lain

f. Penggarap yang tanahnya kurang dari 0,5 hektar;

g. Pemilik yang luas tanahnya kurang dari 0,5 hektar;

h. Petani atau buruh tanji lainnya

Tanah-tanah yang dibagi-bagikan itu diberikan dengan hak milik dengan syarat-syarat sebagai berikut:

1) Penerima redistribusi wajib membayar uang pemasukan .

2) Tanah yang bersangkutan harus diberi tanda-tanda batas.

3) Haknya harus didaftarkan kepada kantor pendaftaran tanah untuk memperoleh setifikat hak milik.

4) Menerima redistribusi wajib mengerjakan / mengusahakan tanahnya secara aktif.

5) Setelah dua tahun sejak tanggal ditetapkannya surat keputusan pemberian haknya wajib dicapai kenaikan hasil tanaman setiap tahunnya sebanyak yang ditetapkan oleh dinas pertanian daerah.

6) Yang menerima hak wajib menjadi anggota koperasi pertanian di daerah letak tanah yang bersangkutan.

7) Selama uang pemasukannya belum dibayar lunas hak milik yang diberikan itu dilarang untuk dialihkan kepada pihak lain tanpa ijin terlebih dahulu dari Kepala Agraria Daerah (sekarang Kepala Kantor Pertanahan Kabupaten/Kota). 
JURNAL HUKUM REPLIK

Vol 7 No 2, September 2019

P-ISSN: 2337-9251, E-ISSN: 2597-9094

Kelalaian dalam memenuhi kewajiban - kewajiban atau pelanggaran terhadap larangan tersebut diatas dapat dijadikan alasan untuk mencabut hak milik yang diberikan itu tanpa pemberian sesuatu ganti kerugian.

Pencabutan hak milik itu dilakukan dengan Surat Keputusan Menteri Agraria atau pejabat yang ditunjuk olehnya. Uang pemasukan yang harus dibayar oleh para petani penerima redistribusi ditetapkan berdasarkan harga tanah yang besarnya sama dengan rata-rata jumlah ganti kerugian tiap hektar yang diberikan kepada bekas pemilik di daerah tingkat II yang bersangkutan menurut klasifikasi tanahnya, ditambah biaya administrasi $6 \%$. Uang pemasukan boleh diangsur selama 15 tahun sejak tanggal ditetapkannya surat keputusan pemberian hak milik yang bersangkutan dengan bunga $3 \%$ pertahun.

Dan sekarang berdasarkan Peraturan Kepala Badan Pertanahan Nasional No.3 tahun 1991 tentang Peraturan Penguasaan Tanah Obyek Landreform Secara Swadaya, bahwa kepada petani yang memperoleh tanah obyek landreform secara swadaya membayar ganti rugi kepada bekas pemilik tanah melalui Kepala Kantor Pertanahan Kabupaten/Kota dengan pengendalian Kepala Kantor Wilayah Badan Pertanahan Nasional Propinsi yang bersangkutan.

Para pemilik tanah absentee yang diambil oleh negara dalam rangka landreform berhak untuk mendapat ganti rugi atas tanah mereka menurut PP Nomor: 224 / 1961 dan PP Nomor: 41 / 1964 ini merupakan ciri utama pelaksanaan landreform di Indonesia yang menunjukkan bahwa tidak ada penyitaan dalam politik pertanahan di Indonesia.

Kepada bekas pemilik tanah absentee diberikan ganti rugi yang besarnya ditetapkan oleh panitia landreform daerah tingkat II yang bersangkutan atas dasar perhitungan perkalian hasil bersih rata - rata selama lima tahun terakhir yang ditetapkan tiap hektarnya menurut golongan kelas tanahnya. Dengan menggunakan degresivited dibawah ini:

a) Untuk 5 hektar yang pertama tiap hektarnya 10 kali hasil bersih setahun;

b) Untuk 5 hektar yang kedua, ketiga, keempat tiap hektarnya 9 kali hasil bersih per tahun;

c) Untuk yang selebihnya tiap hektarnya 7 kali hasil bersih setahun; 
JURNAL HUKUM REPLIK

Vol 7 No 2, September 2019

P-ISSN: 2337-9251, E-ISSN: 2597-9094

Dengan ketentuan bahwa jika harga tanah menurut perhitungan tersebut lebih tinggi dari harga umum, maka harga umumlah yang dipakai untuk menetapkan ganti kerugian tersebut. (pasal 6 ayat (1)). Ganti rugi diberikan sejumlah $10 \%$ dalam bentuk uang simpanan di Bank sedang sisanya berupa Surat Hutang Landreform (SHL). Surat Hutang Landreform tersebut diberi bunga $3 \%$ setahun. Selama pemilik belum dapat mengambil uangnya dibank mendapat bunga $3 \%$ setahun (pasal 7 ayat (1) dan (4) PP No. 224 / 1961).

Berdasarkan pasal II PP No. 41 / 1964 bunga $3 \%$ diubah menjadi 5 $\%$ pertahun. Pada Tahun 1967 Direktur Jenderal Agraria mengeluarkan suatu peraturan hubungannya dengan penyesuaian jumlah ganti rugi untuk obyek - obyek landreform (Peraturan Dirjen Agraria No. 4 Tahun 1967) antara lain ditentukan ganti rugi yang akan dibayar kepada bekas pemilik pada tahun 1968 akan terbatas sampai Rp. 50.000,- .

Berdasarkan Surat Keputusan Menteri Dalam Negeri No. 257 Tahun 1975 tentang Tata Cara Pelaksanaan Tekhnis Pembayaran Ganti Rugi Secara Langsung dinyatakan bahwa para penerima redistribusi asal tanah absentee dan tanah kelebihan dapat melakukan pembayaran ganti rugi secara langsung dengan pembayaran tunai pada suatu waktu tertentu untuk seluruh ganti rugi yang belum dibayar. Pembayaran gantai rugi secara langsung tersebut dilakukan di kantor Kecamatan tempat letak tanah. Lalu lintas pembayaran ganti rugi secara langsung dan biaya administrasi dicatat dan dibukukan secara terpisah oleh Bendaharawan Yayasan Dana Landreform.

\section{Penutup}

\section{Kesimpulan}

Hasil dari penelitian ini dapat diambil beberapa kesimpulan dalam hal pelaksanaan larangan kepemilikan tanah absentee di Kecamatan Mauk diantaranya adala sebagai berikut:

a. Pelaksanaan larangan kepemilikan tanah absentee di Kecamatan Mauk belum bisa dilaksakanakan secara efektif, karena masih banyaknya faktor-faktor yang mempengaruhi seperti faktor masyarakat, budaya, hukum, sarana prasarana, dan ekonomi. Selain beberapa faktor ini ada juga beberapa hal lain yang menyebabkan pelaksanaan ini tidak bisa berjalan degan baik adalah karena tidak adanya sanksi pidana yang tegas terkait larangan kepemilikan tanah absente yang sebagaimana 
JURNAL HUKUM REPLIK

Vol 7 No 2, September 2019

P-ISSN: 2337-9251, E-ISSN: 2597-9094

telah diatur dalam pasal 7, 10, 17, dan 18 Undang-Undang Pokok Agraria yang kemudian diatur dalam Pasal 3 Peraturan Pemerintah nomor 224 Tahun 1961 Tentang Pelaksanaan Pembagian Tanah Dan Pemberian Ganti Rugi. Peraturan untuk larangan ini juga diatur dalam peraturan tambahanya yang terdapat dalam pasal 3a sampai dengan $3 \mathrm{e}$ tentang peraturan yang sama nomor 41 tahun 1964 dan selanjutnya ditegaskan kembali dengan Peraturan Menteri Agraria Dan Tata Ruang/ Kepala Badan Pertanahan Nasional Nomor 18 Tahun 2016 Tentang Pengendalian Penguasaan Tanah Pertanian.

b. Retribusi tanah kepada rakyat yang membutuhkan merupakan sebuah penegakan hukum terhadap larangan pemilikan tanah absente sebagaimana yang tercantum dalam pasal Pasal 3 ayat 5 PP No. 224/1961 jo PP No 41 /1964. Adapun syarat utama bagi penerima tanah retribusi adalah petani penggarap atau buruh tani tetap yang berkewarganegaraan Indonesia, bertempat tinggal di kecamatan tempat letak tanah yang bersangkutan dan kuat bekerja dalam pertanian.

\section{Saran}

Kritik ilmiah atau saran dalam penulisan karya tulis ini diharapkan bisa memberikan masukan atau pandangan bagi para instansi yang berkaitan dengan pertanahan terutama Badan Pertanahan Nasional, adapun saran dalam pelaksanaan larangan kepemilikan tanah absente adalah sebagai berikut:

a. Bagi masyarakat, agar lebih memahami kembali bagaimana mekanisme atau prosedur pembelian tanah pertanian yang berada diluar kecamatan domisi tempat tinggal masyarakat tersebut, agar tidak terjadi penyelewangan secara hukum dalam transaksi jual beli tanah

b. Bagi pemerintah dalam hal ini adalah BPN Kabupaten Tangerang agar lebih sering melakukan sosialisasi kepada masyarakat bawah terkait bagaimana larangan pemilikan tanah secara absente, dan menjelaskan akibat hukum yang akan terjadi ketika terjadi transaksi jual beli tanah. 
JURNAL HUKUM REPLIK

Vol 7 No 2, September 2019

P-ISSN: 2337-9251, E-ISSN: 2597-9094

\section{Daftar Pustaka}

Departemen Pendidikan dan Kebudayaan. Kamus Besar Bahasa Indonesia. Jakarta: Balai Pustaka, 2001.

Harsono, Budi. Hukum Agraria Indonesia, Jakarta: Djambatan, 2002. Hukum Agraria Indonesia, Jakarta : Djambatan, 2008.

Harsono, Budi. Hukum Agraria Indonesia, Sejarah Pembentukan Undang-Undang Pokok Agraria Isi dan Pelaksaannya, Jilid I Hukum Tanah Nasional, Jakarta: Djambatan ,1994.

Harsono, Budi. Hukum Agraria Indonesia, Sejarah Pembentukan Undang-Undang Pokok Agraria, Isi dan Pelaksanaannya. Jakarta : Djambatan, 2005.

Hutagalung, S Arie, dkk, Hukum Pertanahan di Belanda dan Indonesi. Bali: Pustaka Larasan, 2012.

John M. Echols dan Hasan Sadily, Kamus Inggris-Indonesia, Jakarta : Gramedia, 1996.

Maria S.W. Sumardjono, Kebijakan Pertanahan, Antara Regulasi dan Implementasi, Jakarta : Penerbit Buku Kompas, 2005

Nawawi, Hadar. Metode Penelitian Bidang Sosial, Yogyakarta: Gajah Mada University Press, 1993.

Perangin, Effendi. Hukum Agraria di Jakarta, Suatu Telaah dari Sudut Pandang Praktisi Hukum. Jakarta : CV. Rajawali, 1986.

Perangin, Effendi. Hukum Agraria Indonesia, Suatu Telaah Dari Sudut Pandang Praktisi Hukum. Jakarta: Raja Grafindo, 1994.

Salindeho, John. Masalah Tanah dalam Pembangunan. Jakarta : Sinar Grafika, 1993.

Suparman, Usman. Hukum Agraria Indonesi ,Serang : Suhada Press, 2009.

Supriadi. Hukum Agraria, Cetakan Keempat. Jakarta:Sinar Grafika,2010.

Undang-Undang No. 5 Tahun 1960 Peraturan Pokok-Pokok Agraria

Peraturan Pemerintah No. 224 Tahun 1961 tentang Pelaksanaan Pembagian Tanah dan Ganti Rugi

Undang-Undang Dasar 1945

Undang-Undang Nomor 5 Tahun 1960 tentang Peraturan Dasar Pokok-Pokok Agraria Undang-Undang Nomor 56 Prp Tahun 1960 tentang Penerapan Luas Tanah

Pertanian, dan Pelaksanaannya

Peraturan Pemerintah Nomor 224 tahun 1961 tentang Pelaksanaan Pembagian Tanah dan Pemberian Ganti Rugi

Peraturan Pemerintah Nomor 41 Tahun 1964 tentang Perubahan dan Tambahan Peraturan

Peraturan Pemerintah Nomor 4 Tahun 1977 tentang Pemilikan Tanah Pertanian Secara Guntai (Absentee) Bagi Para Pensiunan Pegawai Negeri. 
JURNAL HUKUM REPLIK

Vol 7 No 2, September 2019

P-ISSN: 2337-9251, E-ISSN: 2597-9094

Peraturan Menteri Dalam Negeri Nomor 15 Tahun 1974 tentang Pedoman Tindak lanjut Pelaksanaan land Reform.

Undang-Undang Nomor 4 Tahun 2003 tentang Kebijakan Nasional di Bidang Pertanahan.

Peraturan Presiden Nomor 10 Tahun 2006 tentang Badan Pertanahan Nasional.

Anastasia Apsari Astutiningsih, Isharyanto, peran kantor pertanahan terhadap pelaksanaan larangan kepemilikan tanah secara absenteel guntai di kabupaten sukoharjo, Jurnal Repertorium, Vol. Vol. No. 1 Tahun 2018 https://jurnal.uns.ac.id/repertorium/article/view/18222 diakses pada tangga; 14 juli 2018 pukul 11:30 WIB

Jimly Asshiddiqie, Penegakan Hukum, Makalah yang dipublikasikan dalam http://jimly.com/ pemikiran/makalah?page=12, 2002, diakses pada tanggal 25 Juli 2018 Pukul 21:45

Esthi Maharani, Mauk dan Sepatan Ditetapkan Sebagai Lumbung Padi Abadi, https://www.republika.co.id/berita/nasional/jabodetabeknasional/15/04/19/nn1s51-Mauk-dan-sepatan-ditetapkan-sebagai-lumbungpadi-abadi, diakses pada tanggal 16 Juli 2018 Pukul 21:35 WIB

Sigit Budi Prabowo, Iwan Permadi dan Agus Yuliyanto Pemilikan Tanah Pertanian Secara Absentee Dan Pertanggung Jawaban Hukum Badan Pertanahan Kabupaten Boalemo Atas Penerbitan Sertifikat Program Studi Magister Kenotariatan, Fakultas Hukum Universitas Brawijaya https://media.neliti.com/media/publications/117998-ID-pemilikan-tanahpertanian-secara-absente.pdf diakses pada tanggal 20 Juli 2018 Pukul 23:00 WIB 